\title{
Editorial
}

\section{Hubo elecciones y no se violó la Constitución}

Hubo elecciones y no se violó la Constitución Política, sin embargo ser perdió la oportunidad de alcanzar la paz. Tenemos nuevos gobernantes electos pero igual sigue la guerra con su secuela de muerte y destrucción. Para algunos salvadorefios, integrantes de las mayorias populares que votaron a favor de ARENA existe, por ahora, la esperanza de que van a resolver sus problemas; algunos quizas logren un puesto público que les de para medio vivir, pero la gran mayoría más temprano que tarde comprenderá que mientras no se logre la paz, las posibilidades de reactivar la economia son muy pocas y por consiguiente la disminución del desempleo no parece posible y éste precisamente es uno de los grandes problemas que enfrenta la mayoría de la población. Además de este problema real, que sencillamente es imposible de resolver en las actuales circunstancias, ¿qué dirán aquellos que votaron por ARENA cuando el nuevo gobierno siguiendo orientaciones neoliberales devalúe la moneda y la inflación, ligeramente controlada, vuelva a cobrar nuevos y mayores impulsos?

Los problemas económicos-sociales que enfrenta El Salvador han alcanzado tales magnitudes que ni aún en condiciones normales - sin guerra y con un nivel de producción equivalente al de 1978- pueden ser superados con sólo sustituir en la administración pública un partido por otro. $Y$ el objetivo prioritario de cualquier Estado, obviamente, debe de ser alcanzar el bienestar social, no sólo porque es deber constitucional, sino porque los gobernantes son depositarios de la voluntad popular y resulta impensable que los salvadorefios hayan renunciado a su voluntad de vivir. Pero no se puede vivir si no se tienen los medios materiales para satisfacer las necesidades básicas y para quien su única fuente de ingreso es su trabajo, si no logra encontrar una ocupación 
remunerada, pues no tiene posibilidad de vivir. De alli que nos parece que los salvadorenos mas que ilusiones democráticas, necesitamos un proyecto de sociedad capaz de enfrentar la problemática de las mayorías populares, sólo entonces, un gobierno seria el legitimo representante del pueblo salvadorefio.

Es por esa razón que no nos parece como relevante el que haya votado tan sólo el $37 \%$ de los salvadoreños en edad de votar o que el total de votos válidos tan sólo haya alcanzado el $50 \%$ de los votos posibles, ya no digamos el hecho de que el actual gobierno sea la manifestación del $26.9 \%$ de los votos posibles y de una proporción poco significativo de la población en edad de votar, habida cuenta que el total de votos válidos apenas corresponde a poco más de un tercio de esa población. Aunque ello debería de servir para calmar la euforia y las desmedidas pretensiones de quienes embriagados por el triunfo electoral, imaginan que han aniquilado cualquiera otra fuerza politica o que cuentan con el mandato de todo un pueblo para hacerto por otros medios.

Ciertamente con el triunfo de ARENA hay espectativas de que la polarización: gobierno-empresa privada va a desaparecer, sin embargo. lo más probable es que al interior del mismo partido en el poder comiencen a presentarse algunas contradicciones, cuando se definan realmente las políticas que orientarán la futura gestión pública. Además de ello, al eliminarse las contradicciones entre el gobierno y la empresa privada, se fortalecerá la polarización entre ellos y la clase trabajadora, debido a que la contradicción de intereses entre patronos y trabajadores no puede sencillamente eliminarse con solo negar su existencia y si se concilian las políticas del gobierno con la empresa privada, obviamente, deberán afectar a los trabajadores. Tal fenómeno conducirá a una mayor efervecencia popular, que seguramente se tratará de deslegitimar haciéndola parecer tan sólo como fruto de la acción política del FMLN, e incluso gustarian de reprimir violentamente a la población trabajadora, aunque ello vendría a reafirmar la imagen negativa que posee ARENA en el exterior y complicaría la obtención de la "ayuda" económica proveniente de la administración Bush, sin la cual, incluso, el nuevo gobierno apoyado por el gran capital no podría funcionar. De tal manera que aunque un nuevo partido nos gobierne, las viejas tensiones seguirán presentes y ahora, quizas, con mayor fuerza.

Bien, hubo elecciones y no se violó la Constitución, pero igual pudieron haberse pospuesto, el FMLN habria participado en ellas y ahora, otro seria el horizonte. Pero los partidos mayoritarios: el triuntador ARENA y el derrotado PDC, optaron por la lormalidad legal, antes que por la búsqueda del bienestar real para todos los salvadorefios, y es así como se ha perdido una excelente oportunidad de abandonar el camino 
de las armas y éstas, al menos para el FMLN, adquieren una nueva justificación generada por dos razonamientos realmente infundados: el creer posible la reactivación económica pese a la guerra y el imaginar una victoria militar sobre el FMLM. Ambas tesis han sido refutadas por la realidad histórica de los últimos años, no obstante ello, se piensa que bastaria con cambiar la modalidad de conducción de la administración pública y de la guerra, para lograr los pretendidos objetivos. Seguramente para una pequeńa fracción de la población ello resulta lo más deseable, ya que de esa manera no habría necesidad de enfrentar las causas reales que generan el conflicto, y que puede resumirse en lo que se ha dado en llamar injusticia estructural. Pero también en este punto hay cierta falsificación de la realidad, porque así como no se puede abolir el robo eliminando físicamente a quienes roban, tampoco se puede acabar con el fenómeno llamado "subversión" eliminando a los subversivos. Si la realidad fuese tan simple, como se les presenta a las mentes excesivamente ideologizadas, resultaria que, o bien, las bajas del FMLN que reporta el ejército son talsas o los guerrilleros son inmortales, dado que el accionar militar de los insurrectos, llámesele como se le quiera llamar, lejos de disminuir tiende a incrementarse, alcanzando cada vez con más fuerza el área Metropolitana, la cual durante mucho tiempo parecia ser una negación a la realidad de la guerra que asolaba el resto del pais.

Hubo elecciones y la ilusión de democracia que estas generan sigue presente, pero las elecciones no constituyen el contenido real de la democracia, incluso, la libertad política y de expresión, tan ponderadas por el régimen demócrata-cristiano, no tienen una significación real para la mayoria de la población, si ésta no logra satisfacer sus necesidades materiales básicas y fundamentales. Para que el hombre pueda satisfacer sus necesidades espirituales, previamente habrá de haber satisfecho sus necesidades materiales. Hay una verdad que por obvia, no deja de ser verdad: para vivir en democracia primero hay que estar vivo. $Y$ es la vida la que precisamente se niega con la insatisfacción de las necesidades sociales y con la continuación de la guerra.

marzo de 1989. 